\title{
Analiza i przegląd narzędzi ankietowych stosowanych w diagnostyce i rehabilitacji narządu słuchu u dzieci w pierwszych latach życia - przegląd literatury
}

\section{Analysis and overview of questionnaires used in hearing diagnostics and evaluation of auditory rehabilitation progress in the first years - literature review}

\author{
Anita Obrycka, Artur Lorens \\ Instytut Fizjologii i Patologii Słuchu, Światowe Centrum Słuchu, Zakład Implantów i Percepcji Słuchowej, \\ Warszawa/Kajetany
}

Adres autora: Anita Obrycka, Światowe Centrum Słuchu, Zakład Implantów i Percepcji Słuchowej, ul. Mokra 17, Kajetany, 05-830 Nadarzyn, e-mail: a.obrycka@ifps.org.pl

\section{Streszczenie}

W pracy dokonano przeglądu i analizy narzędzi ankietowych stosowanych w diagnostyce i ocenie postępów rehabilitacji narządu słuchu u dzieci w pierwszych latach życia. Wśród narzędzi poddanych analizie wyłącznie kwestionariusze PEACH i LittlEARS charakteryzuje odpowiednia trafność i rzetelność potwierdzająca ich wysoką jakość pomiarową w tej grupie dzieci. Tylko wyniki badania kwestionariuszami IT-MAIS, LittlEARS i PEACH można porównać z wynikami uzyskiwanymi przez dzieci ze słuchem prawidłowym. Spośród wyżej wymienionych jedynym narzędziem zwalidowanym w języku polskim jest kwestionariusz LittlEARS.

Słowa kluczowe: kwestionariusz • niedosłuch • percepcja słuchowa

Abstract

This paper presents an overview and analysis of questionnaires used in hearing diagnostics and evaluation of auditory rehabilitation progress in the first years of life. From among all investigated instruments the psychometric properties of only PEACH and LittlEARS questionnaires confirm their high measurement quality in this group of children. Only results of tests performed using the IT-MAIS, LittlEARS and PEACH can be compared with the results achieved by children with normal hearing. Out of the above specified questionnaires only the LittlEARS has been validated in the Polish language.

Key words: questionnaires • hearing loss • auditory perception

\section{Wprowadzenie}

Badania kwestionariuszowe w diagnostyce niedosłuchu oraz w ocenie postępów rehabilitacji słuchowej cieszą się coraz większym zainteresowaniem specjalistów. Zastosowanie kwestionariuszy pozwala na poszerzenie diagnostyki pacjenta o aspekty związane $z$ subiektywną oceną efektów leczniczo-rehabilitacyjnych lub też odnoszące się do oceny jakości życia związanej ze zdrowiem. Metody kwestionariuszowe są szczególnie przydatne w przypadku dzieci z niedosłuchem do oceny ich rozwoju słuchowego po zastosowaniu aparatów słuchowych lub implantu ślimakowego. Ogólny model rozwoju słuchowego dziecka dokonuje podziału rozwoju percepcji słuchowej na trzy główne poziomy: poziom detekcji dźwięku prowadzący do tzw. świadomości dźwięku; poziom dyskryminacji umożliwiający rozróżnianie dźwięków oraz poziom identyfikacji odpowiedzialny za rozpoznawanie dźwięków i interpretację tego, co słyszymy [1]. W praktyce surdologopedycznej wyróżnia się natomiast pięć etapów rozwoju percepcji słuchowej: wykrywanie - detekcja, różnicowanie - dyskryminacja, identyfikacja, rozumienie mowy, rozumienie mowy na tle dźwięków zakłócających [2]. Stosowane w diagnostyce badania audiologiczne u dzieci w pierwszych latach życia dostarczają jedynie informacji o możliwości detekcji bodźców akustycznych i nie pozwalają na ocenę rozwoju słuchowego dziecka w zakresie dyskryminacji i identyfikacji dźwięków, a w szczególności w zakresie percepcji mowy. 
Informacji takich mogą dostarczyć badania kwestionariuszowe, które pozwalają na usystematyzowaną ocenę rozwoju słuchowego dziecka w pierwszych latach życia, obejmującą wszystkie poziomy percepcji słuchowej, począwszy od odbioru bodźców akustycznych (detekcja), poprzez odpowiednią reakcję na te bodźce (dyskryminacja i identyfikacja), zachowania komunikacyjne będące manifestacją rozwoju słuchowego, aż do rozumienia mowy. Kwestionariusze stosowane w diagnostyce i ocenie postępów rehabilitacji dzieci odwołują się głównie do obserwacji dziecka dokonanych przez rodzica w warunkach życia codziennego lub terapeuty w warunkach klinicznych. Liczne badania potwierdzają, że kwestionariusze mogą dostarczyć rzetelnych informacji o rozwoju dziecka [3-6]. Jednakże znaczenie diagnostyczne mają jedynie kwestionariusze prawidłowo przygotowane, zwalidowane, o znanych i odpowiednich właściwościach psychometrycznych, to znaczy takie, co do których istnieje pewność, że uzyskane z ich wykorzystaniem wyniki są trafne i rzetelne [7-9]. Trafność i rzetelność pomiarowa kwestionariusza wpływa na możliwość sensownego intepretowania uzyskanego wyniku.

Celem pracy jest dokonanie przeglądu i analizy narzędzi ankietowych stosowanych $\mathrm{w}$ diagnostyce i ocenie postępów rehabilitacji narządu słuchu u dzieci w pierwszych latach życia. Praca ma charakter poglądowy, powstała jako efekt przeglądu subiektywnie wybranych pozycji piśmiennictwa odnalezionych w bazach PubMed i Google Scholar, bez zastosowania analizy systematycznej.

\section{Kwestionariusze stosowane $w$ diagnostyce oraz ocenie postępów rehabilitacji słuchowej u dzieci w pierwszych latach życia}

Obecnie metoda oceny rozwoju słuchowego małego dziecka z wykorzystaniem kwestionariuszy jest stosowana w praktyce klinicznej coraz powszechniej. Od kilkunastu lat pojawiają się nowe narzędzia, większą wagę przykłada się też do ich walidacji. Coraz częściej kwestionariusze stają się rekomendowanym narzędziem wspomagającym ocenę audiologiczną. W rekomendacjach bierze się pod uwagę tylko narzędzia zwalidowane, o znanych i odpowiednich właściwościach psychometrycznych oraz takie, dla których zostały wyznaczone normy pozwalające na porównanie wyników z wynikami dzieci prawidłowo słyszących [10].

Z przeprowadzonego przeglądu literatury wynika, że do grupy kwestionariuszy przeznaczonych dla niemowląt i małych dzieci należą:

a) IT-MAIS (ang. Infant-Toddler Meaningful Auditory Integration Scale) [11],

b) PEACH (ang. Parent's Evaluation of Aural/Oral Performance of Children) [12,13],

c) ELF (ang. Early Listening Function) [14],

d) FAPI (ang. Functional Auditory Performance Indicators) [15],

e) LittlEARS $[16,17]$.

\section{Kwestionariusz IT-MAIS}

Kwestionariusz IT-MAIS jest modyfikacją kwestionariusza MAIS (ang. Meaningful Auditory Integration Scale) przeznaczonego do oceny percepcji dźwięków i adekwatnej na nie reakcji w sytuacjach życia codziennego u dzieci $\mathrm{z}$ niedosłuchem, $\mathrm{w}$ wieku szkolnym, korzystających $\mathrm{z}$ różnego rodzaju protez słuchowych [18]. IT-MAIS natomiast przeznaczony jest do oceny rekcji słuchowych oraz ekspresji wokalnej niemowląt i małych dzieci na podstawie obserwacji poczynionych przez rodzica w warunkach życia codziennego. Zawiera dziesięć pytań obejmujących trzy obszary zachowania słuchowego dziecka: wokalizowanie, uwaga słuchowa, wyodrębnianie znaczenia dźwięków. Badanie $\mathrm{w}$ formie wywiadu strukturalnego przeprowadzane jest przez klinicystę. Rodzic nie wypełnienia kwestionariusza samodzielnie, uzyskany w ten sposób wynik uznawany jest za nieważny. Klinicysta notuje odpowiedzi rodzica na poszczególne pytania kwestionariusza i następnie ocenia je w skali od 0 do 4 , w zależności od częstości pojawiania się zachowania, o które pyta (0 - nigdy nie zaobserwowano określonego zachowania, 4 - zachowanie obserwowane zawsze) [11]. Wynik badania jest sumą ocen dla poszczególnych pytań. Wynik może być porównany z wynikiem poprzedniego badania, daje to możliwość oceny postępów rehabilitacji słuchowej dziecka po zastosowaniu aparatów słuchowych lub implantu ślimakowego.

Kwestionariusz został opracowany w języku angielskim. Badania walidacyjne tego kwestionariusza prowadzono dla trzech wersji językowych: angielskiej, niemieckiej i polskiej w grupie dzieci korzystających z implantu ślimakowego [19]. Autorzy wskazali brak rzetelności pomiarowej dla dwóch pierwszych pytań kwestionariusza (dotyczących ekspresji wokalnych dziecka). wyjaśniając, że przyczyną braku rzetelności pomiarowej może być zbyt mała liczebność badanej grupy. Ponadto wskazali na obniżenie powtarzalności pomiarowej w badaniu przeprowadzonym 6 miesięcy po pierwszej administracji kwestionariusza, tłumacząc je zmianą osoby wypełniającej kwestionariusz (rodzic zamiast klinicysty). Jednocześnie autorzy postulują prowadzenie dalszych badań walidacyjnych kwestionariusza IT-MAIS [19].

Walidację kwestionariusza prowadzono również w populacji 120 dzieci prawidłowo słyszących, posługujących się językiem mandaryńskim. Kwestionariusz został zaadaptowany do języka mandaryńskiego, a następnie poddany walidacji w grupie dzieci w wieku poniżej dwóch lat. Właściwości psychometryczne kwestionariusza wskazują na wysoką rzetelność i trafność pomiarową w tym języku, potwierdzoną wysoką zgodnością wewnętrzną testu (współczynnik alfa Cronbacha=0,96, współczynnik lambda Guttmanna=0,96), wysoką mocą dyskryminacyjną jego pozycji (wartość współczynnika korelacji pozycja-skala $>0,70$ ) oraz silną korelacją wyniku badania i wieku dziecka (zastosowany model logarytmiczny wyjaśnia $88 \%$ wariancji wyników) [20]. Autorzy wyłączyli z badania pytanie $\mathrm{nr} 1$, ponieważ nie dotyczy ono dzieci ze słuchem prawidłowym (odnosi się do wokalizacji dziecka po włączeniu aparatów słuchowych lub implantu ślimakowego). Wykazali również dużą zgodność wyników walidacji dla pytań 3-10 z wynikami uzyskanymi w badaniach prowadzonych przez Weichbold i współpracowników [19]. Potwierdzili również wysoką jakość pytania nr 2 [20].

Odpowiednia trafność i rzetelność pomiarowa kwestionariusza $\mathrm{w}$ grupie dzieci ze słuchem prawidłowym nie stanowi dowodu na trafność i rzetelność IT-MAIS w grupie dzieci z niedosłuchem. Przedstawione powyżej wyniki badań 
walidacyjnych wskazują na konieczność weryfikacji dwóch pierwszych pytań kwestionariusza, określenie warunków prowadzenia badania, tak aby dla wszystkich badaczy był jednoznaczny, oraz ponowne przeprowadzenie walidacji.

\section{Kwestionariusz PEACH}

Kwestionariusz PEACH (ang. Parent's Evaluation of Aural/Oral Performance of Children) opracowany został w języku angielskim. Przeznaczony jest do oceny skuteczności rehabilitacji niemowląt i dzieci do wieku szkolnego. Jedna wersja narzędzia ma postać usystematyzowanego wywiadu dla rodziców (PEACH Diary) [12], druga postać pięciopunktowej skali oceny (PEACH Rating Scale) [13]. Obie wersje zawierają 13 pytań dotyczących umiejętności słuchania i komunikowania się dziecka w ciszy oraz w hałasie, używania telefonu, reakcji na dźwięki otoczenia. Kwestionariusz PEACH Diary rodzice zabierają do domu i przez tydzień dokonują obserwacji zachowań słuchowych dziecka określonych przez pytania. Zapisują te obserwacje na specjalnie przygotowanych arkuszach. Rodzice przy każdym pytaniu notują także wszystkie odnoszące się do niego przykłady zachowań słuchowych swojego dziecka. Następnie obserwacje rodzica oceniane są przez audiologa w skali pięciopunktowej od 0 do 4, w zależności od częstości występowania danego zachowania słuchowego. Oceny audiologa są sumowane, dając wynik końcowy. Prowadzenie badania z wykorzystaniem tego kwestionariusza jest czasochłonne i musi być poprzedzone dodatkowym przeszkoleniem osoby prowadzącej badanie pod kątem analizowania odpowiedzi rodziców, tak żeby wyniki były wiarygodne, rzetelne. Niedoświadczony badacz może mieć kłopot z oceną, który z przykładów podanych przez rodzica można zaliczyć do zachowań słuchowych dziecka.

Walidację kwestionariusza PEACH Diary przeprowadzono w grupie dzieci $\mathrm{z}$ normą słuchową oraz w grupie dzieci z niedosłuchem, wyznaczono również normy dla obu grup. Kwestionariusz cechuje wysoka zgodność wewnętrzna (współczynnik alfa Cronbacha=0,88), świadcząca o wysokiej rzetelności pomiaru dokonywanego za pomocą tego narzędzia. Poszczególne pozycje kwestionariusza charakteryzują się wysoką mocą dyskryminacyjną (wartości współczynnika korelacji pozycja-skala powyżej 0,40; wartość powyżej 0,2 uznaje się za wystarczającą, aby włączyć pozycję do kwestionariusza [21]). Ponadto wyznaczona krzywa normatywna charakteryzuje się silną korelacją wyniku badania i wieku dziecka (zastosowany model regresji logistycznej wyjaśnia $82 \%$ wariancji wyników) [22].

Badanie kwestionariuszem PEACH Rating Scale przeprowadzane jest w klinice. Nie jest wymagana tygodniowa obserwacja i podawanie przykładów zachowań dziecka. Rodzic odpowiada na pytania kwestionariusza, oceniając w skali od 0 do 4 , jak często obserwował dane zachowanie słuchowe, gdzie 0 (nigdy: 0\% sytuacji), 1 (rzadko: 1-25\% sytuacji), 2 (czasami: $26-50 \%$ sytuacji), 3 (często: $51-75 \%$ sytuacji), 4 (zawsze: $76-100 \%$ sytuacji) [13].

Walidacja kwestionariusza PEACH Rating Scale przeprowadzona przez Ching and Hill wykazała, że jedenaście z czternastu pytań cechuje wysoka moc dyskryminacyjna oceniona na podstawie analizy wartości współczynników korelacji pozycja-skala oraz odpowiednia zgodność wewnętrzna (współczynnik alfa Cronbacha $=0,88$ ). Autorzy uznali swoje badania za wstępne i wskazali na konieczność ich kontynuowania [22]. Badania kontynuowane przez Bagatto i Scollie pozwoliły na uzupełnienie dowodów potwierdzających trafności i rzetelność pomiarową kwestionariusza poprzez ocenę korelacji wyniku badania i wieku dziecka (zastosowany logistyczny model regresji wyjaśnia $62 \%$ wariancji wyników), porównania wartości normatywnych dla badania PEACH Rating Scale i PEACH Diary (współczynnik korelacji pomiędzy krzywymi normatywnymi $r=0,98$ ) oraz badania rzetelności pomiaru poprzez ocenę zgodności wewnętrznej (współczynnik alfa Cronbacha $=0,78)$ [23].

\section{Kwestionariusz ELF}

Kwestionariusz ELF (ang. Early Listening Function) przeznaczony jest do oceny reakcji słuchowych dziecka $\mathrm{z}$ wadą słuchu, korzystającego z różnego rodzaju urządzeń wspomagających słyszenie. Ocena dokonywana jest na podstawie zaobserwowanych przez rodzica reakcji dziecka na wybrane dźwięki (np. szept, klaskanie, dźwięk wody płynącej $\mathrm{z}$ kranu, pukanie do drzwi, śpiew) dobiegające $\mathrm{z}$ różnych odległości $(10 \mathrm{~cm}$, ok. $1 \mathrm{~m}, 2 \mathrm{~m}, 3 \mathrm{~m}$, z innego pokoju) i w różnych sytuacjach akustycznych (w ciszy, w hałasie) [14]. Rodzice oceniają reakcje dziecka w trzech kategoriach: dziecko reaguje na dany dźwięk, nie reaguje, rodzic nie potrafi jednoznacznie ocenić. Każdy wynik cząstkowy wchodzi do wyniku całkowitego z odpowiednią wagą. Przeprowadzenie badania wymaga dokładnego przeszkolenia rodziców, dotyczącego poziomu prezentacji bodźca oraz sytuacji, w jakich należy obserwować reakcje dziecka.

Zgodnie $\mathrm{z}$ intencją twórcy kwestionariusz ELF nie jest narzędziem diagnostycznym (brak walidacji, brak norm), jego rolą jest pomoc w ocenie reakcji słuchowych u dziec$\mathrm{ka} \mathrm{z}$ wadą słuchu po zastosowaniu rehabilitacji słuchowej $\mathrm{z}$ wykorzystaniem danej technologii medycznej. Kwestionariusz nie dotyczy obserwacji dziecka w sytuacjach codziennych, jest formą kontroli treningu reakcji słuchowych dziecka przeprowadzaną przez rodzica $z$ użyciem określonych w kwestionariuszu bodźców prezentowanych w zadanych warunkach.

\section{Kwestionariusz FAPI}

Kwestionariusz FAPI (ang. Functional Auditory Performance Indicators) służy do oceny umiejętności wykorzystania funkcji słuchowych [15]. Może być używany jako narzędzie do oceny rozwoju słuchowego $\mathrm{z}$ wykorzystaniem obserwacji zarówno rodzica, jak i terapeuty. Kwestionariusz zawiera listę umiejętności słuchowych uporządkowanych zgodnie $\mathrm{z}$ etapami rozwoju słuchowego dziecka. Pytania pogrupowane są w 7 kategorii: świadomość i znaczenie dźwięków, integracja i reakcja zwrotna na dźwięki, lokalizacja źródła dźwięku, dyskryminacja dźwięków, rozumienie, krótkotrwała pamięć słuchowa, językowe przetwarzanie słuchowe. Każda kategoria zawiera po kilka pozycji dotyczących określonych umiejętności słuchowych dziecka. Ocena dla każdej kategorii składa się z ważonej sumy ocen dla każdej umiejętności słuchowej. Waga każdej umiejętności słuchowej zależy od tego, czy dziecko wykorzystuje wskazówki 
wizualne, czy prezentuje określoną umiejętność, wykorzystując jedynie drogę słuchową, z daleka/z bliska, w ciszy/w hałasie, gdy ktoś zwróci jego uwagę/spontanicznie). Każde zachowanie słuchowe oceniane jest w różnych sytuacjach akustycznych, w czteropunktowej skali, w zależności od częstotliwości występowania.

Walidacja tego kwestionariusza nie została dotychczas opublikowana, nie można zatem ocenić jego przydatności klinicznej. Nie wyznaczono również norm ani dla dzieci ze słuchem prawidłowym, ani dla dzieci z niedosłuchem. W literaturze można zapoznać się jedynie z brazylijską adaptacją kwestionariusza do języka portugalskiego [24]. Autorzy przeprowadzili tylko adaptację językową, bez badania właściwości psychometrycznych kwestionariusza i bez wyznaczenia wartości normatywnych. Ponadto autorzy powyższej adaptacji w podsumowaniu stwierdzają, że badanie $\mathrm{z}$ wykorzystaniem kwestionariusza FAPI jest czasochłonne i często niemożliwe do przeprowadzenia w czasie jednej sesji z dzieckiem. Zdarza się również, że ocena rodzica nie jest zbieżna $\mathrm{z}$ oceną terapeuty. Autorzy wskazują również na pewne wady wynikające $\mathrm{z}$ niedoprecyzowania warunków oceny reakcji dziecka przez twórców kwestionariusza, dotyczące między innymi poziomu prezentacji bodźca, poziomu szumu, braku ścisłego zdefiniowania określeń takich jak: $\mathrm{z}$ daleka, z bliska [24].

\section{Kwestionariusz LittlEARS}

Kwestionariusz LittlEARS służy do oceny rozwoju percepcji słuchowej dzieci w wieku do 24 miesięcy $[8,9,16,17]$. Odzwierciedla najistotniejsze fazy rozwoju słuchowego dziecka w przedsłownym okresie rozwoju mowy [25]. Zawiera 35 pytań, na które rodzice odpowiadają, wybierając jedną z dwóch odpowiedzi „tak” lub „nie”. Większość pytań została uzupełniona przykładami. Pytania uporządkowane są zgodnie z kolejnymi etapami rozwoju słuchowego dziecka. Większość z pierwszych 16 pytań kwestionariusza dotyczy zdolności do detekcji i dyskryminacji dźwięków. Pytania te obejmują rozwijające się w pierwszych miesiącach życia umiejętności związane ze słuchowym sprzężeniem zwrotnym towarzyszącym gaworzeniu, uwagą słuchową i umiejętnościami lokalizacyjnymi, rozwojem reakcji na bodźce akustyczne niewerbalne - np. dźwięki otoczenia (zabawki, przedmioty domowe, muzyka) oraz werbalne - dźwięki mowy. Kolejne pytania kwestionariusza 10, 12, 17-21 i 25-30 dotyczą głównie zdolności percepcyjnych związanych z identyfikacją dźwięków, tj. reakcji na imię, rozpoznawania wypowiedzi o zabarwieniu emocjonalnym, kojarzenia dźwięków z obiektami. Pytania 22-24 oraz 31-35 związane są z rozwojem rozumienia, manifestującym się umiejętnością wykonywania pojedynczych poleceń lub ich sekwencji, skupiania uwagi na słowie czytanym.

Kwestionariusz LittlEARS jest prosty w użyciu i interpretacji wyników, wypełnienie kwestionariusza zajmuje rodzicowi ok. 10-15 minut. Łączny wynik badania kwestionariuszem LittlEARS jest sumą wszystkich odpowiedzi „tak”. Uzyskany wynik porównywany jest z wartością oczekiwaną - zależną od wieku średnią uzyskiwaną przez dzieci ze słuchem prawidłowym, i z wartością minimalną - oznaczającą, że wartości poniżej tej granicy uzyskało $<5 \%$ dzieci w danej grupie wiekowej. Osiągnięcie łącznego wyniku
LittlEARS poniżej wartości minimalnej może wskazywać na nieprawidłowy rozwój słuchowy.

Walidacja wersji oryginalnej kwestionariusza LittlEARS przeprowadzona została w grupie 218 dzieci o słuchu prawidłowym [16,17]. Właściwości psychometryczne kwestionariusza wskazują na wysoką rzetelność i trafność pomiarową, potwierdzoną wysoką zgodnością wewnętrzną testu (współczynnik alfa Cronbacha=0,96, współczynnik lambda Guttmanna $=0,93$, rzetelność $\mathrm{w}$ teście połówkowym (splithalf reliability) $r=0,88$ ) oraz wysoką mocą dyskryminacyjną jego pozycji. Uzyskana dodatnia korelacja $r=0,91$ wskazuje na bardzo wysoką zależność liczby uzyskanych odpowiedzi "tak” od wieku dziecka (im starsze dziecko, tym bardziej prawdopodobne jest uzyskanie większej liczby punktów) i tym samym potwierdza, że kwestionariusz LittlEARS dokonuje oceny rozwoju słuchowego [16,17].

Kwestionariusz LittlEARS został zaadaptowany do języka polskiego zgodnie $\mathrm{z}$ aktualnymi standardami dotyczącymi adaptacji testów psychologicznych [26,27]. Walidacja polskiej wersji kwestionariusza przeprowadzona została w grupie 310 dzieci ze słuchem prawidłowym. Trafność pomiaru kwestionariuszem potwierdzono poprzez ocenę mocy dyskryminacyjnej poszczególnych pytań (wartość współczynnika korelacji pozycja-skala powyżej 0,2 dla 32 pytań kwestionariusza), rozkładu wartości współczynnika trudności (rosnąca wartość współczynnika trudności pytania wraz z jego numerem wskazuje na to, że struktura polskiej wersji kwestionariusza pozostaje $\mathrm{w}$ zgodzie $\mathrm{z}$ wersją oryginalną) oraz wysoką korelację wyniku kwestionariusza $\mathrm{z}$ wiekiem dziecka $(\mathrm{r}=0,90, \mathrm{p}<0,001)$. Uzyskana dla kwestionariusza wartość współczynnika alfa Cronbacha $=0,95$ świadczy o tym, że polska wersja kwestionariusza LittlEARS jest narzędziem o wysokiej rzetelności pomiarowej $[8,9,28]$.

Obecnie kwestionariusz LittlEARS jest dostępny w 26 wersjach językowych. Opublikowane wyniki badań wieloośrodkowych opisują wyniki walidacji kwestionariusza przeprowadzonej w 15 językach (flamandzkim, bułgarskim, mandaryńskim, fińskim, francuskim, niemieckim (Austria), greckim, polskim, rumuńskim, rosyjskim, serbskim, słowackim, słoweńskim, niemiecki (Szwajcaria), angielskim (USA) i hiszpańskim (USA) charakteryzują odpowiednie właściwości psychometryczne [29]. Ponadto zbliżone krzywe normatywne dla wszystkich wersji językowych dowodzą o kulturowej i językowej uniwersalności narzędzia, jakim jest kwestionariusz LittlEARS. Podobne wyniki uzyskali również autorzy adaptacji kwestionariusza do języka arabskiego i hebrajskiego [30] oraz angielskiego (Kanada) [31].

Założeniem twórców kwestionariusza LittlEARS było jego zastosowanie w grupie dzieci z niedosłuchem, korzystających z aparatów słuchowych lub implantu ślimakowego, jako narzędzia pozwalającego na monitorowanie tempa i stopnia rozwoju słuchowego u dzieci w pierwszych latach życia. Kwestionariusz LittlEARS został również zwalidowany $w$ tej grupie dzieci. Potwierdzono także jego przydatność do oceny postępów rehabilitacji dzieci z niedosłuchem w pierwszych latach życia $[9,32]$. 
Tabela 1. Zestawienie wybranych cech i charakterystyk analizowanych kwestionariuszy

Table 1. Comparison of selected features and characteristics of analyzed questionnaires

\begin{tabular}{|c|c|c|c|c|c|c|}
\hline & $\begin{array}{l}\text { IT-MAIS } \\
\text { [11] }\end{array}$ & $\begin{array}{l}\text { PEACH Rating } \\
\text { Scale } \\
{[12,13]}\end{array}$ & $\begin{array}{l}\text { PEACH Diary } \\
{[12]}\end{array}$ & $\begin{array}{l}\text { ELF } \\
{[14]}\end{array}$ & $\begin{array}{l}\text { FAPI } \\
{[15]}\end{array}$ & $\begin{array}{c}\text { LittlEARS } \\
{[8,16,17,29]}\end{array}$ \\
\hline $\begin{array}{l}\text { Język opracowania } \\
\text { kwestionariusza }\end{array}$ & angielski & angielski & angielski & angielski & angielski & niemiecki \\
\hline $\begin{array}{l}\text { Odpowiednia trafności } \\
\text { i rzetelność } \\
\text { pomiarowa }\end{array}$ & nie & tak & tak & nie & nie & tak \\
\hline $\begin{array}{l}\text { Liczba wersji } \\
\text { językowych }\end{array}$ & 4 & brak danych & 5 & brak danych & 2 & 26 \\
\hline $\begin{array}{l}\text { Polska wersja } \\
\text { o odpowiedniej } \\
\text { trafności } \\
\text { i rzetelności }\end{array}$ & nie & nie & nie & nie & nie & tak \\
\hline $\begin{array}{l}\text { Możliwość porównania } \\
\text { wyników z wynikami } \\
\text { dzieci z normą } \\
\text { słuchową }\end{array}$ & tak & tak & tak & nie & nie & tak \\
\hline $\begin{array}{l}\text { Obliczenie } \\
\text { i interpretacja wyniku }\end{array}$ & łatwe & skomplikowane & łatwe & skomplikowane & skomplikowane & łatwe \\
\hline $\begin{array}{l}\text { Osoba wypełniająca } \\
\text { kwestionariusz }\end{array}$ & klinicysta & rodzic & rodzic & rodzic & $\begin{array}{l}\text { rodzic/ } \\
\text { klinicysta }\end{array}$ & rodzic \\
\hline $\begin{array}{l}\text { Uwagi dotyczące } \\
\text { przebiegu badania }\end{array}$ & $\begin{array}{l}\text { wymagane } \\
\text { szkolenie } \\
\text { klinicysty }\end{array}$ & $\begin{array}{l}\text { wymagane } \\
\text { szkolenie } \\
\text { klinicysty }\end{array}$ & $\begin{array}{l}\text { badanie łatwe do } \\
\text { przeprowadzenia }\end{array}$ & $\begin{array}{l}\text { konieczne } \\
\text { przeszkolenie } \\
\text { rodzica }\end{array}$ & $\begin{array}{l}\text { badanie } \\
\text { skomplikowane } \\
\text { i czasochłonne }\end{array}$ & $\begin{array}{l}\text { badanie łatwe do } \\
\text { przeprowadzenia }\end{array}$ \\
\hline
\end{tabular}

\section{Podsumowanie}

Tabela 1 przedstawia porównanie wybranych cech i charakterystyk kwestionariuszy zidentyfikowanych na podstawie literatury. Aby kwestionariusze mogły być używane w praktyce klinicznej, powinny charakteryzować je następujące cechy:

- nieskomplikowana procedura badania,

- łatwość obliczania i interpretacji wyników,

- możliwość porównania wyników do normy,

- odpowiednia trafność i rzetelność pomiarowa.

Spośród przedstawionych narzędzi jedynie badania $\mathrm{z}$ wykorzystaniem kwestionariuszy PEACH Rating Scale i LittlEARS cechuje nieskomplikowana procedura badawcza, niewymagająca dodatkowego szkolenia klinicysty i rodzica. Biorąc pod uwagę łatwość obliczania i interpretacji wyników, jest ona nieskomplikowana w przypadku kwestionariuszy IT-MAIS, PEACH Rating Scale i LittlEARS

Tylko wyniki badania kwestionariuszami IT-MAIS, LittlEARS i PEACH można porównać $\mathrm{z}$ wynikami uzyskiwanymi przez dzieci ze słuchem prawidłowym. Celem rehabilitacji medycznej jest dążenie do przywrócenia normy funkcjonalnej. Zatem jedną z możliwych metod oceny postępów rehabilitacji słuchowej jest porównanie do normy wyników uzyskanych w efekcie tej rehabilitacji [32]. Wykorzystanie kwestionariusza LittlEARS w ocenie postępów rehabilitacji słuchowej pozwala dodatkowo na ilościową ocenę tych postępów poprzez obliczenie opóźnienia rozwoju słuchowego. Procedura opisana w artykule Obryckiej i wsp. [33] umożliwia dokonanie oceny skuteczności nowych technologii medycznych u dzieci poniżej drugiego roku życia już w pierwszych miesiącach po ich zastosowaniu, bez konieczności prowadzenia długookresowych obserwacji.

Spośród powyżej opisanych narzędzi wyłącznie PEACH i LittlEARS charakteryzuje odpowiednia trafność i rzetelność pomiarowa. Odpowiednia trafność pomiarowa gwarantuje, że dokonujemy pomiaru zakładanej cechy, a rzetelność świadczy o dokładności tego pomiaru. Obydwa parametry wpływają na możliwość sensownego intepretowania uzyskanego wyniku. Biorąc pod uwagę przedstawione zalety kwestionariusza IT-MAIS, wydaje się zasadne przeprowadzenie poszerzonych badań walidacyjnych tego kwestionariusza także w języku polskim. Celowe również wydaje się przeprowadzenie adaptacji kwestionariusza PEACH Rating Scale do języka polskiego, ponieważ pozwala na ocenę postępów rehabilitacji również dzieci w wieku powyżej dwóch lat.

Obecnie jedynym zwalidowanym w języku polskim narzędziem spośród opisanych powyżej jest kwestionariusz LittlEARS. Ponadto jest on narzędziem kulturowo i językowo uniwersalnym. Oznacza to, że może być używany w międzynarodowych badaniach wieloośrodkowych $\mathrm{z}$ uwagi na możliwość bezpośredniego porównania wyników.

Obecnie jedynie w przypadku kwestionariuszy LittlEARS i PEACH istnieją należyte dowody na trafność i rzetelność pomiarów prowadzonych $\mathrm{z}$ ich wykorzystaniem. Pomimo iż podjęto próbę opracowania wielu kwestionariuszy, jak te opisane powyżej oraz inne przeznaczone dla dzieci starszych, nadal brakuje prac potwierdzających trafność i rzetelność pomiarową tych narzędzi. Prace takie powinny być 
kontynuowane, gdyż istnieje potrzeba opracowania trafnych, rzetelnych oraz kulturowo i językowo uniwersalnych narzędzi kwestionariuszowych, uzupełniających diagnostykę niedosłuchów u dzieci w różnych grupach wiekowych oraz pozwalających na ocenę postępów rehabilitacji po zastosowaniu różnego rodzaju interwencji.
Publikacja powstała $w$ zwiazku $z$ realizacja projektu pn. „Zintegrowany system narzędzi do diagnostyki i telerehabilitacji schorzeń narząów zmysłów (słuchu, wzroku, mowy, równowagi, smaku, powonienia)" INNOSENSE, wspólfinansowanego przez Narodowe Centrum Badań i Rozwoju w ramach Programu STRATEGMED.

Projekt zostat sfinansowany ze środków Narodowego Centrum Nauki przyznanych na podstawie decyzji numer DEC-2013/09/B/ ST7/04213.

\section{Piśmiennictwo:}

1. Carney AE. Audition and the development of oral communication competency. W: Bess FH, Gravel JS, Tharpe AM, red. Amplification for children with auditory deficits. Nashville: Bill Wilkerson Center Press, 1996.

2. Skarżyński H, Szuchnik J, Mueller-Malesińska M. Implanty ślimakowe - rehabilitacja. Warszawa: Stowarzyszenie Przyjaciół Osób Niesłyszących i Niedosłyszących, 2004.

3. Allum D. Cochlear implant rehabilitation in children and adults. London: Whurr Publishers, 1996.

4. Hoey H, McGee H, Fitzgerald M, Mortensen H, Hougaard P i wsp. Parent and health professional perspectives in the management of adolescents with diabetes: development of assessment instruments for international studies. Qual Life Res, 2006; 15: 1033-42.

5. Watson L, Baranek G, Crais E, Reznick S, Dykstra J, Perryman T. The first year inventory: retrospective parent responses to a questionnaire designed to identify one-year-olds at risk for autism. J Autism Dev Disord, 2007; 37: 46-61.

6. Cole E, Flexer C. Children with hearing loss developing listening and talking, birth to six. San Diego, CA: Plural Pub, 2007.

7. Osterlind Constructing test items: multiple-choice, constructed-response, performance, and other formats. Boston, Dordrecht, London: Kluwer Academic Publishers, 2001.

8. Obrycka A, Padilla J, Pankowska A, Lorens A, Skarżyński H. Production and evaluation of a Polish version of the LittlEars questionnaire for the assessment of auditory development in infants. Int J Pediatr Otorhinolaryngol, 2009; 73: 1035-42.

9. Obrycka A. Adaptacja i wykorzystanie kwestionariusza LittlEARS. Rozprawa doktorska, 2014.

10. Bagatto M, Moodie S, Malandrino A, Richert F, Clench D, Scollie S. The University of Western Ontario Pediatric Audiological Monitoring Protocol (UWO PedAMP). Trends Amplif, 2011; 15: 57-76.

11. Zimmerman-Phillips S, Osberger M, Robbins A. Infant-Toddler Meaningful Auditory Integration Scale. Sylmar, CA: Advanced Bionics Corp, 1997.

12. Ching T, Hill M. P.E.A.C.H Diary. 2005. Pobrane z: http://outcomes.nal.gov.au/.

13. Ching T, Hill M. Parents' Evaluation of Aural/Oral Performance of Children (P.E.A.C.H.). 2005. Pobrane z: http://outcomes. nal.gov.au.

14. Anderson K. ELF - Early Listening Function. 2002. Pobrane z: www.southalabama.edu/alliedhealth/speechandhearing/ eadams/ELF_Questionnaire.pdf.

15. Stredler-Brown A, Johnson D. Functional auditory performance indicators: an integrated approach to auditory development. 2001. Pobrane z: http://www.tsbvi.edu/attachments/FunctionalAuditoryPerformanceIndicators.pdf.

16. Tsiakpini L, Weichbold V, Kühn-Inacker H, Coninx F, D'Haese P. Almadin S. LittlEARS Auditory Questionnaire Manual. Innsbruck: MED-EL, 2004.
17. Weichbold V, Tsiakpini L, Coninx F, D’Haese P. Development of a parent questionnaire for assessment of auditory behaviour of infants up to two years of age. Laryngorhinootologie, 2005; 84: $328-34$.

18. Robbins A, Renshaw J, Berry S. Evaluating meaningful auditory integration in profoundly hearing-impaired children. Am. J. Otol., 1999; 12: 144-50.

19. Weichbold V, Anderson I, D'Haese P. Validation of three adaptations of the Meaningful Auditory Integration Scale (MAIS) to German, English and Polish. Int J Audiol, 2004; 43: 156-61.

20. Zheng Y, Soli S, Wang K, Meng J, Meng Z, Xu K. A normative study of early prelingual auditory development. Audiol Neurotol, 2009; 14: 214-22.

21. Fronczyk K. Psychometria. Warszawa: Vizja Press \& IT, 2009.

22. Ching T, Hill M. The Parents' Evaluation of Aural/Oral Performance of Children (PEACH) scale: normative data. J Am Acad Audiol, 2007; 18: 220-35.

23. Bagatto M, Scollie S. Validation of the Parents' Evaluation of Aural/Oral Performance of Children (PEACH) Rating Scale. J Am Acad Audiol, 2013; 24: 121-25.

24. Ferreira K, Moret A, Bevilacqua M, Rde S. Translation and adaptation of functional auditory performance indicators (FAPI). J Appl Oral Sci, 2011; 19: 586-98.

25. Northern J, Downs M. Hearing in children. Baltimore: Williams \& Wilkins, 1991.

26. International Test Commission (2010) International Test Commission guidelines for translating and adapting tests. Pobrane $\mathrm{z}$ : http://www.intestcom.org.

27. American Educational Research Association, American Psychological Association, National Council on Measurement in Education Revised Version of Standards for Educational and Psychological Testing. AERA, 2014.

28. Obrycka A, Piotrowska A, Lorens A, Pankowska A, Padilla J, Skarżyński H. Adaptacja kwestionariusza LittlEARS do języka polskiego. Now Audiofonol, 2013; 2: 33-39.

29. Coninx F, Weichbold V, Tsiakpini L, Autrique E, Bescond G, Tamas L i wsp. Validation of the LittlEARS ${ }^{\circledast}$ Auditory Questionnaire in children with normal hearing. Int J Pediatr Otorhinolaryngol, 2009; 73: 1761-68.

30. Geal-Dor M, Jbarah R, Meilijson S, Adelman C, Levi H. The Hebrew and the Arabic version of the LittlEARS ${ }^{\oplus}$ Auditory Questionnaire for the assessment of auditory development: results in normal hearing children and children with cochlear implants. Int J Pediatr Otorhinolaryngol, 2011; 75: 1327-32.

31. Bagatto M, Brown C, Moodie S, Scollie S. External validation of the LittlEARS ${ }^{\circledast}$ Auditory Questionnaire with English-speaking families of Canadian children with normal hearing. Int J Pediatr Otorhinolaryngol, 2011; 75: 815-17. 
32. Obrycka A, Lorens A, Piotrowska A, Skarżyński H. Ocena rozwoju słuchowego dzieci z głębokim niedosłuchem, którym wszczepiono implant ślimakowy we wczesnym dzieciństwie. Now Audiofonol, 2014; 3: 59-65.
33. Obrycka A, Lorens A, Piotrowska A, Skarżyński H. Wykorzystanie kwestionariusza LittlEARS do oceny skuteczności interwencji związanej ze stosowaniem implantu ślimakowego u małych dzieci z głębokim niedosłuchem. Now Audiofonol, 2014; 3: $52-58$. 